III.-Briiish Fossil Crinoids.-IV. Thenarocrinus gracilis, sp. nov., Wenlock Limestone, and Note on T. callipygus. By F. A. Bather, M.A., F.G.S.

\title{
[Plate I.]
}

\section{A. Note on Thenarocrinus callipygus.}

Some seven weeks after the publication of Paper III., "On Thenarocrinus callipygus" *, my friend Mr. W. Madeley of Dudley sent me an excellent specimen of that species which he had found in the cabinets of Mr. C. B. Ketley of Smethwick. The collection of the late Mr. Charles Ketley is for the most part in the museum of Mason's S'cience College at Birmingham, and it may be remembered that three of the finest specimens of $T$. callipygus are there to be found. Some of the collection is, however, still in the possession of Mr. C. B. Ketley, and it is remarkable that it should contain this other even more instructive specimen of so rare a species. My best thanks are due to its owner for the ready loan of this interesting fossil:

The specimen appears to come from the same horizon and locality as all the others, viz. the Upper Wenlock Limestone of Dudiley.

The specimen is a complete crown broken away from the stem at the second or third joint. Its interest lies in the fact that it is seen from the posterior, and that the anal plates and lower portion of the ventral sac are very clearly displayed in their natural positions. In no other specimen known to me is the anal area shown so clearly or completely; hence in the preceding paper it could only be represented by a reconstructed and composite diagram (Diag. 1, p. 227). The figure of the present specimen (Pl. I. fig. 3) proves the essential truth of this diagram.

It was stated on p. 228 that slight variations existed, hence we are not surprised to find the present individual departing in one or two minor particulars from the more usual type. Thus, the first plate of both the distichous series is axillary, and not the second as was stated on p. 228 to be generally the case. In the tetrastichous series the first plate on the inner right hand is seen to bear two small plates, but these again support only one. Such variations have no systematie value, but it would be unwise, while we are yet in the dark as 
to the true meaning of the ventral sac, to assert that they are of no morphological importance.

The large size of the posterior infra-basal, caused by its rising up to meet the radianal, is noteworthy, especially in connexion with the possible Carabocrinid affinities of this genus.

In this species the angle which the side of the cup makes with the long axis is not $93_{5}^{\circ}$, as erroneously stated on p. 225 , but is $15^{\circ} 15^{\prime}$.

I take this opportunity of publishing better representations of the British Museum specimens $57478 a$ (Pl. I. fig. 2) and $57478 b$ (Pl. I. fig. 1) ; these correspond to figures 3 and 5 of plate x. ('Annals,' 1890, vol. vi.).

\section{B. Thenarocrinus gracilis, $s p$. nov.}

This species is founded on a specimen in the general collection of the Museum of the Yorkshire Literary and Philosophical Society at York. Although I saw this specimen when examining the Crinoids of that museum in September 1889, yet, as the genus Thenarocrinus was not then formulated, the relationship of this species to T'. callipygus escaped my notice. Unfortunately the existence of this specimen only recurred to me after Paper III. had gone to press. It is with little doubt a Thenarocrinus, and, being entrusted to me through the kindness of my friend Mr. H. M. Platnauer, Secretary to the Yorkshire Literary and Philosophical Society, I hasten to describe it. It would have been better to have procured yet other specimens, but none are known to me, and it seems advantageous to publish a description while on the subject of Thenarocrinus, instead of laying it aside to be again forgotten.

The specimen (Pl. I. fig. 4 ) is a crown with 6 millim. of stem attached; it lies in the matrix, but is fortunately seen from the posterior. Formerly in the possession of Mr. Edward Wood, of Richmond, Yorkshire, it was in 1880 bought along with the rest of that gentleman's specimens by John Reed, Esq., M.R.C.S., of York, and by him presented with the whole of his collection to the Literary and Philosophical Society.

The specimen retains Mr. Wood's original label, which runs as follows:- "Cyathocrinus (showing Proboscis), Silurian, Dudley." It obviously comes from the Upper Wenlock Limestone.

\section{Diagnosis.}

Cup conical, rather elongate; plates mostly higher than 
wide. Arms about six times length of cup, slender, dichotomize about five times; arm-ossicles, when seen from back, about as high as wide; lateral compression very slight. Anal plates situated low in the cup. Stem (so far as known) smooth.

The graceful and slender appearance suggests gracilis as a natural nomen triviale.

\section{Description of Specimen.}

Dorsal cup forms a cone the sides of which are almost in a line with the gradually tapering proximal part of the stem below and with the arms above; thus its elongate character is exaggerated. The measurements are:-Breadth at base $3 \cdot 2$ millim.; breadth at summit 6.5 millim.; height of cup 5.5 millim. The specimen, however, is obviously flattened in the plane of bedding; the stem, for instance, is so crushed that its section, instead of forming a circle, is an ellipse with axes in the proportion of nearly $3: 2$; the cup, as one would expect, is crushed more than the stem, and the proportions may be taken as quite $3: 2$. 'The true measurements would thus be:-Breadth at base 2.7 millim.; at summit 5.4 millim. Consequently the angle which the side of the cup makes with the long axis is about $13^{\circ} 47^{\prime}$.

IB. presumably 5 , of which 4 should be pentagonal. Only the two posterior are seen: r. post. IB. pentagonal, with height about equal to breadth; l. post. IB. abnormally wide, of somewhat uncertain relations, but probably with truncate top supporting post. B.

B. presumably 5 and hexagonal. Only post. B. is completely seen; portions of $\mathrm{r}$. and $\mathrm{l}$. post. BB. are visible. They would appear to have been about as high as wide. The post. B., however, is higher than wide, and its distal angle is truncated by a small plate which seems to belong to the tegmen: this is probably an individual abnormality.

R. presumably 5, though only 2 are seen: higher in proportion than in type species, with articular facet apparently more excavated. 'The l. post. R. is cut short on the side next the anal area by the tegminal plate that was mentioned as resting on the post. B.: this feature also is probably an individual abnormality.

Arms have, by reason of their slenderness, a longer appearance than those of $T$. callipygus; but, owing to the greater height of the cup, their length relatively to it is less, namely six instead of seven times its height. The extent of their dichotomy cannot be exactly ascertained, but their free 
brachials are probably only the third postpalmars, instead of the sixth as in $T$. callipygus, a fact that further enhances the graceful slimness of the arms. The arm-ossicles are smooth with a very slight constriction in the middle, and a very slight swelling, hardly to be called a ridge, anteriorly. The height of the ossicles is about equal to their breadth all the way up the arms. Lateral compression is more obvious in the proximal than in the distal region of the arms, and may in this case be due to simple mechanical pressure by the rock. More distally the arms have almost a flat shallow appearance. The ventral surface of the arms is nowhere exposed.

Costals, in r. post. arm apparently 9 . The edges of the proximal costals in each ray are bent upwards parallel to the curved edges of the radial facet. There is no bevelling of the outer edge as in the type species.

The remainder of the arms is too fragmentary to allow the number of distichals, palmars, \&c. to be more than guessed at: the average number in each series was probably about 10 .

Anal structures :-Radianal, since it rests on both $r$. and $l$. post. IB., is hexagonal, not pentagonal; in correlation with this it is higher than wide : in other respects as in type species.

Brachianal not shield-shaped, but an irregular hexagon, very slightly higher than wide. Normally it was probably situated as in T. callipygus, but in the present specimen it is separated from l. post. R. by the tegminal plate before alluded to.

The connexion of the ventral sac with the anal plates is as follows (see Pl. I. fig. 5). The Brachianal does not support a second brachianal, but is itself axillary. The first plate of the left-hand distichous series is axillary, and the same appears to be the case with the corresponding plate on the right. Then follow series of folded plates so like those of $T$. callipygus that further description is unnecessary; the anticlinal folds, however, are a little broader proportionally than in that species.

In the present specimen the ventral sac attained a length of at least 24 millim.

The Tegmen, beyond a few small plates on either side the origin of the ventral sac, is not seen in this specimen.

The Stem (Pl. I. tig. 5) is smooth in the proximal portion, and this smoothness does not appear to be due to rubbing. There are 23 ossicles preserved, of alternating height but regularly decreasing diameter. The smaller ones are about half the lieight of the larger, so that approximate measurements are :- height $\cdot 34$ and $\cdot 17$ millim.; diameter $2 \cdot 7$ 
to 1.66 millim. There is a very slight trace of a radial suture in what would normally be the l. post. radius, but, owing to the abnormalities of the infrabasal circlet, this suture appears to lie in the posterior interradius. The axial canal appears to have been large, but its exact size cannot be determined.

\section{General Remarks.}

To our knowledge of the morphology of Thenarocrinus the present species adds but little; the following points may, however, be noticed. First, it entails a slight modification of the diagnosis (l.c. p. 224), which must now read " $R$ ' in Basal circlet, resting on one or more post. IB." Secondly, from the evidence of this specimen, combined with that of specimens of T. callipygus, it is certain that at least four out of the eight ridges of the ventral sac arise by dichotomy from the brachianal. Lastly, we must mark the absence of a second brachianal, for in nearly all genera of Fistulata that plate is present: in the few cases where it cannot be distinguished, in other words where the first brachianal is itself axillary, the two plates may possibly have fused; certain facts render this explanation probable, but there is nothing in the present specimen that makes either for or against it.

The small size of this specimen, as compared with the specimens of $T$. callipygus, may suggest that it died young. But the fully developed plication of the plates in the ventral sac is more powerful evidence of its maturity.

Certain features in the present specimen, since they appear to be abnormalities rather than specific characters, find no place in the diagnosis. They are, however, of some interest from a morphological point of view, especially as it is not easy to see how they arose. The sinking of a tegminal plate, on the left of the posterior interradius, so low that it rests on the posterior basal, is no doubt in accordance with the general development of this genus, and tends to counteract the greater narrowness of the cup in the present species; at the same time it would be rash to regard so unusual a structure as more than an individual variation.

The relations of the left posterior infrabasal to the posterior basal, though probably obtaining throughout the species, are very remarkable, and more material is required for their complete elucidation. It is even possible that, if all future specimens were found to possess the many curious characters of the present one, the establishment of a new genus would be warrantable. But under any circumstances the species would remain close to $T$. callipygus. Systematically considered 
T. gracilis is indeed less differentiated in most points than T. callipygus; the essential features of the genus are present, but in the structure of the arms and general shape of the cup the form before us is closely connected with the ordinary Dendrocrinite type.

\section{EXPLANATION OF PLA'TE I.}

\section{A. Thenarocrinus callipygus, Bather.}

Fig. 1. 57478 b B. M. Previously figured Ann. \& Mag. Nat. Hist. ser. B, vol. vi. pl. x. fig. 5. This shows the tegminal plates, which were not rendered by the lithographer, and the broad ventral sac. (Nat. size.)

Fig. 2. 57478 a, B. M. Previously figured loc. cit. fig. 3. Shows fine branching of arms, a few tegminal plates, and, on the left, the base of the ventral sac; in the stem is seen the trace of a radial suture. (Nat. size.)

Fig. 3. Mr. C. B. Ketley's specimen. Shows anal area and base of ventral sac. Distally the arms are somewhat broken, disordered, and rubbed. The lower part of the cup is damaged by fracture. (Nat. size.)

B. Thenarocrinus gracilis, sp. nov.

Fig. 4. Specimen in York Museum. (Nat. size.)

Iig. 5. The lower part of the same outlined to show arrangement of plates and stem-cssicles. $(\times 4$.)

IV.-List of Lepidoptera in a Collection made by Emin Pasha in Central Africa. By Arthur G. Butler, F.L.S., F.Z.S., \&c.

THE present collection consists of eighty species, chiefly of Rhopalocera; only two of the species appear to be actually new to science, although several others have only been described comparatively recently.

By far the greater number of the recognized species are identical with forms found in South Africa, and in all cases where closely allied representative forms occur in the south and west, the southern form is the one represented in the present collection; the eastern element is very slightly indicated.

R H O P A L OCERA.

Nymphalidæ.

1. Tirumala petiverana.

Danais limniace, var. petiverana, Doubleday, Gen. Diurn. Lep. pl. xii. fig. 1 (1847). 


\section{$2 \mathrm{BHL}$ Biodiversity Heritage Library}

Bather, Francis Arthur. 1891. "III.-British fossil crinoids.-IV. Thenarocrinus gracilis, sp. nov., Wenlock Limestone, and note on T. callipygus." The Annals and magazine of natural history; zoology, botany, and geology 7, 35-40. https://doi.org/10.1080/00222939109460575.

View This Item Online: https://www.biodiversitylibrary.org/item/63422

DOI: https://doi.org/10.1080/00222939109460575

Permalink: https://www.biodiversitylibrary.org/partpdf/59166

\section{Holding Institution}

University of Toronto - Gerstein Science Information Centre

\section{Sponsored by}

University of Toronto

\section{Copyright \& Reuse}

Copyright Status: NOT_IN_COPYRIGHT

This document was created from content at the Biodiversity Heritage Library, the world's largest open access digital library for biodiversity literature and archives. Visit BHL at https://www.biodiversitylibrary.org. 